\title{
COMPARISON OF TRAINING PROGRAMMES AND ACTIVITIES FOR CLUSTER MANAGERS IN EUROPE WITH RESPECT TO THEIR FOCUS ON SKILLS DEVELOPMENT
}

\author{
Martin HORÁK, Jana MATOŠKOVÁ \\ Faculty of Management and Economics of Tomas Bata University in Zlín
}

\begin{abstract}
The role of cluster manager and his/her development is an essential element in order to gain a competitive advantage and to ensure sustainability of cluster organisation. Nevertheless, research on cluster management has hardly studied the scope of offered trainings with areas of developed skills for this position. Hence, the main objective of the paper is to analyze and evaluate content of current training programmes for cluster managers in Europe with respect to their focus on the development of hard and soft skills. Analyzed training programmes were chosen based on the consultations with members from National Cluster Association operating in the Czech Republic. Regarding the defined criterion, hard skills included terms related to specific cluster knowledge (tools/methods for cluster setting/development; cluster policy), knowledge in management area. Meanwhile, we understood soft skills as terms related to intrapersonal skills (one's ability to manage oneself) and interpersonal skills (how one handles one's interactions with others). The article was processed via desktop research involving collection of relevant information from secondary sources. The paper explores ten international programmes done across Europe. Based on the gathered data, we claim that analyzed programmes are overwhelmingly focused on developing hard skills (mainly specific knowledge and abilities required for success in the cluster manager position - such as knowledge about identifying cluster, tools and methods for development of clusters). However, based on the literature, it is clear that soft skills (intrapersonal and interpersonal skills) are crucial for sustainable development of organisation. Considering implications for the practice, our findings provide valuable point for organisations/initiatives offering training programmes for cluster managers.
\end{abstract}

\section{KEY WORDS}

cluster, cluster organisation, cluster management, cluster manager, training programmes.

\section{JEL CLASSIFICATION}

P13, O31.

\section{INTRODUCTION}

The concept of cluster and clustering has been popular among many researchers (see Swann \& Prevezer, 1996; Knorringa \& Meyer-Stamer, 1998; Cooke, 2001; Martin \& Sunley, 2003; Steiner \& Hartmann, 2006). However, the most accepted definition of the cluster is from American professor 
and economist Michael Porter. Porter (1990) defined cluster as "geographic concentrations of interconnected companies, specialized suppliers, service providers, firms in related industries and associated institutions (universities, standards agencies, and trade associations) in particular fields that compete but also cooperate." The main objective common to all of the clusters is to strengthen the competitiveness of participating companies, which means providing their products and services more effectively than their competitors. Being a member of a cluster is beneficial for participating companies as well as for universities and regional government. For example, Mazilu and Sava (2011) in their paper list following benefits: the clusters can reduce the barriers of the market and determine the creation of new enterprises and business models, they can stimulate and create strong synergies, they help companies to find resources, technologies and knowledge and facilitate ideas to transform in opportunities of businesses. Therefore, cluster can be seen as an important tool to increase competitiveness of involved actors and whole regions/countries.

Nowadays more scholars are starting to give focus also on ways clusters are managed (Ingstrup and Damgaard, 2013; Schretlen et al., 2011; Sölvell, Lindqvist and Ketels, 2003) and on the importance of cluster manager/leader (Sydow et al., 2011; Zagorsek et al., 2008; Barry, 1991; Menu, 2012; Jarjabka and Weiner, 2012). It is because the performance and sustainability of the cluster depends mainly on the quality of cluster manager (Sölvell, Lindqvist and Ketels, 2003). The impact of management appears to be a crucial success factor for cluster performance (Gebhardt \& Pohlmann, 2013; Günther \& Meissner, 2017) and recent experience provides evidence that a professional management has a positive role to develop and keep a cluster (Günther \& Meissner, 2017). When the person in a role of cluster manager is not competent enough, it may have negative consequences on the functioning of the whole cluster (Sölvell, Lindqvist and Ketels, 2003). According to Jarjabka and Weiner (2012) and Zagorsek et al. (2008), the training and the education of the cluster manager plays an important role in the success of the cluster's life. Doronina et al. (2016) add that without the necessary, qualified employees, any organization will not be able to achieve the objectives and to carry out the activity. Gebhardt and Pohlmann (2013) found out that not a lot of cluster managers will distinguish themselves in mastering complexity of management. Thus, the researchers should start giving more attention to the cluster management development. However, possible international training activities for cluster managers have not been investigated broadly among scholars yet. Furthermore, their scope and area of developed skills are limited in the literature. Hence, we stated following research questions:

- Which training programmes are offered to cluster managers within Europe?

- Which skills are being developed within these programmes?

The main objective of our paper is to analyze and evaluate content of current training programmes for cluster managers in Europe with respect to their focus on the development of hard and soft skills.

The article is structured as follows: chapter 1 introduces definitions of cluster organisation, cluster management, activities carried out by the cluster manager, which is followed by the development of managers in general; chapter 2 describes used methodology; chapter 3 focuses on an analysis of training programmes and activities for cluster managers on the international level. The next section presents results and discussion. Finally, a conclusion and suggestions for the direction of future research are given.

\section{LITERATURE REVIEW}

In our paper, we focus on the development of cluster managers skills with respect to current training programmes in Europe. Therefore, it is firstly needed to define term as cluster organization and to describe the position of cluster manager including his work agenda. Afterwards, we point out the 
importance of management development with the emphasis to developing areas of skills and composition of successful training programme for managers.

\section{The role of cluster manager in cluster organization}

Cluster manager is in charge of formalised institution called cluster organisation. Meanwhile, clusters are perceived as natural groups of companies and associated institutions; cluster organisation (CO) is defined by Schretlen et al. (2011) as „organised efforts to facilitate cluster development, which can take various forms, ranging from non-profit associations, through public agencies to companies." A cluster organisation has a legal entity, whose form is selected by stakeholders with respect to functionality of a cluster organisation in some specific sectoral conditions. The task of the CO is according to Břusková et al. (2013) to create a favorable environment for cooperation within the cluster to ensure strategic and dynamic development, the identification of joint projects, training and support innovative business.

Day-to-day management and development of the $\mathrm{CO}$ is ensured by the project team, headed by the cluster manager. Günther and Meissner (2017) define cluster management as "all organizational and managerial work within a cluster that contributes to improved interconnectedness between cluster members (internal relations) and between the cluster and surrounding actors (external relations)." In this context, Břusková et al. (2013) argue that the interest of stakeholders in the quality of cluster manager from the beginning is critical to the success of the cluster, because he / she is the person who creates the necessary environment of confidence in the cluster and ensures its stability. Similarly, Pavelkova et al. (2009) add that the foreign cluster managers see the most important aspects leading to the success of the cluster in quality management, which is connected with a clear definition of objectives, the vision of the cluster and the strategic plan, as well as mutual trust, willingness to cooperate and proactivity of members. The manager thus acts as an intermediary between the members of the $\mathrm{CO}$ and stimulates collaboration inside and outside of the cluster. Some authors perceive the position of the cluster manager as identical to a cluster facilitator (Ingstrup and Damgaard, 2013). However, a cluster facilitator is rather defined as a person who has a key role in the initial stages of formation and development of the cluster (Pavelkova et al., 2009). In contrast, the cluster manager role is especially in the daily management of the cluster, hence in the implementation of the strategy and in realisation of the proposed activities. As Pavelkova et al. (2009) state, it cannot be automatically assumed that a proven cluster facilitator will automatically becomes its manager.

A cluster manager in cooperation with cluster members formulates vision, goals and strategies, and within his/her agenda is also organizing joint activities. In research conducted by Pro INNO Europe Initiative (2009), it was found that cluster managers across Europe must fulfill a number of tasks related to this profession. The predominant activity is networking, which involves creating and developing contacts, the inclusion of new members and the strengthening of the exchange of experience among cluster members, lobbying activities with stakeholders, managing and organizing joint events and preparing and launching cooperation projects in order to develop the appropriate CO. CLOE (2006) classifies the activities carried out by cluster management into five basic areas:

- networking,

- human resources (including staff training through courses, seminars, conferences),

- research and innovation (sharing information and ideas, joint research projects),

- commercial cooperation and promotion (joint purchasing, logistics management, use of a common logo or brand, joint participation in exhibitions, etc.),

- financing investment projects. 
As stated above, the key factor influencing success of the $\mathrm{CO}$ is seen in the role of cluster manager. This person must have the specific properties, knowledge and skills to deal with the cluster management agenda in order to ensure the successful functioning of the CO (Břusková et al., 2013). To successfully carry out activities mentioned above, it is essential that cluster manager participates in the training programmes in order to be competent person. Lack of character traits or skills often leads to negative consequences for the functioning of the cluster organisation and it may lead even to its extinction (Sölvell, Lindqvist and Ketels, 2003). However, it is also important to bear in mind that succesful managers are not born, they are made (Veber, 2014; Northouse, 2013). People may possess an inborn disposition to perform the role of manager, but their personal qualities must be constantly evolved in order to become succesful. This hypothesis is supported by Drucker (2012), who adds that the organisation must allow its members to grow and develop in accordance with their needs and opportunities. In connection with the frequent failure of managers (Ulčín, 2014; Freeman, 2007), it is thus more than desirable to pursue their development. The development of the cluster manager should be seen as one of the key factors affecting the future success of the cluster organisation. This is recognised by countries such as Norway, Germany and Austria, where the local governments see clusters as important tools in region development and therefore they set up regional agencies offering services for cluster managers (Kergel, Köcker and Nerger, 2014). These support services are defined as non-monetary activities aimed at developing cluster management including coaching, training, education, consulting, technical assistance (Kergel, Köcker and Nerger, 2014). However, the research by Kergel, Köcker and Nerger (2014) examined only conditions on the national level. There is no systematic research related to international support activites for cluster management. Thus, in our study, we follow up on work by Kergel, Köcker and Nerger (2014) with comparision of international training programmes and activities for cluster managers. We put the emphasis on developed skills in these programmes because professional management is crucial in the successful cluster development (Günther \& Meissner, 2017).

\section{Development of managers}

Armstrong (2007) suggests that education can be viewed as a continuous process, which not only improves existing capabilities, but also leads to the development of skills, knowledge and attitudes that prepare individuals for the future performance of demanding tasks. The development of skills, knowledge and abilities Armstrong (2007) likens to the evolutionary proces. The goal of education and development is then, according to Urban (2004), increasing the worker's individual performance or team performance. Brodský (2009) adds that further training and development of managers is more than desirable because it helps to increase achievements and also serves as a preparation for higher duties and more responsibility in the future. It is clear that development and continuous education of managers is crucial in order to ensure success in managing an organisation. Studies in this research area deal with several topics. The researchers in the literature are examining either management education in business schools (Salas et al., 2009; Kars-Unluoglu, 2016), management development in organisation (McKenna \& Yeider, 1991; Darling \& Heller 2009; McGurk, 2013; Millar \& Gitsham, 2013), or link between management training and firm performance (Cosh et al., 1998; Fraser et al., 2002; Kitching and Blackburn, 2002; Storey, 2002; Storey, 2004).

Folwarczná (2010) states that the training and development of managers is focused on developing two areas of skills, hard skills and soft skills. Hard skills are closely related mainly to knowledge (e.g. English grammar, accounting) and they can be relatively easy measured (via tests) and trained (Mühleisen a Oberhuber, 2008). Laker and Powell (2011) see them as technical skills that involve working with equipment, data, software, etc. On the other hand, soft skills are more related to personal characteristics, psychological traits, preferences, attitudes and so on. The importance of soft skills and their development is stated among many scholars (Crosbie, 2005; Hunt a Baruch, 2003; Balcar, 2016; Robinson and Stubberud, 2014; Henville, 2012). They are also seen as more important compared to hard skills in the long term (Pro INNO Europe Initiative, 2009). For 
example, Statt (1998) defined them as "a stable, long-lasting, learned predisposition to respond to certain things in a certain way." Laker and Powell (2011) divided them into intrapersonal skills (one's ability to manage oneself) and interpersonal skills (how one handles one's interactions with others). Soft skills generally include interpersonal relationships, working with people, communication and interaction to other individuals and groups. Folwarczná (2010) claims that area of interpersonal relationships is very important for work of managers. Hence, this area is called the soft side of management and is considered as a key in order to master leadership role (Folwarczná, 2010). Lastly, it should be noted that soft skills are hardly measurable, because it's difficult to measure how good listeners people are or how well they are able to negotiate. Their development is slower and more difficult, because improving somebody's cooperation, for example, often requires changing his or her attitudes first and then assisting in the mastery of methods to improve that skill (Balcar et al., 2011).

Another question which arise in this context is how should be composed successful training programme for managers. Firstly, it is important to mention that adult learners have different learning techniques than young ones (Du Plessis et al., 2013). According to Du Plessis et al. (2013) they are "continuous learners and they move in and out of formal education according to individual needs or life circumstances, job requirements or career development." Thus, the programmes should follow specifics of participants. It is also important to follow actual trends and challenges in the management area and modern society. The set of skills for success in manager position is changing over time. Nowadays, the manager should also adapt the leader role which should be reflected in the training programmes (Alvesson \& Sveningsson, 2003). Regarding the cluster environment, the importance of leadership is also mentioned by scholars (Sydow et al., 2011; Zagorsek et al., 2008). This is also supported by Nguyen and Hansen (2016), who suggest that dual approach, the leadingmanaging mix, should be considered. According to Elmuti et al. (2005) and Nguyen and Hansen (2016) the leader-manager programme should be consisted from 3 parts: 1) fundamental knowledge and skills required for both leading and managing (includes hard skills such as the ability to use information technology and soft skills like cultural sensitivity and the ability to communicate with others); 2) understanding leading and managing (learn to switching mindset between leader/manager role); 3) action-based training (learning by practice).

Last but not least, as Tannenbaum and Yukl (1992) state, the selection of training method is crucial when designing training programme. In practice, there are applied two training methods in programmes, such as off the job and on the job. Off the job training takes place in environment other than actual workplace and its designed to meet the shared learning needs of a group (Alipour et al., 2009). This kind of training can takes forms such as: lectures, computer-based training, games and simulations. On the other hand, on the job training is aimed to provide employee with taskspecific knowledge and skills in work area via job rotation, coaching, job instruction technique (Alipour et al., 2009). In order to select balanced approach for effective management development, the organization must consider several factors, such as the amount of funding available for training, specificity and complexity of the knowledge and skills needed, timeliness of training needed, and the capacity and motivation of the learner (Alipour et al., 2009). To conclude, designed training for managers should aim for complex development with emphasis to soft skills as an essential factor in management development.

\section{METHODOLOGY}

The article was processed by using desktop research involving collection of relevant information from secondary sources. Our methodology was divided into following phases:

1. The literature review was conducted. The studies, scientific articles from databases SCOPUS/WoS and monographies regarding clusters, cluster organisations (including their 
management and development of managers) were examined. Selection criteria were the following: date of publication from 1980 to 2017; used keywords for search: cluster, cluster organisation, cluster manager, development of managers.

2. This phase was about setting the main criteria for comparative analysis - categories of hard and soft skills in specific cluster conditions were developed (reflected by the Table 1). As secondary criteria, we choose to analyze following: duration of the programme - short-term ( 1 - 5 days), medium-term ( $2-4$ weeks) and long-term (more than 1 month), place of the programme, organization providing programme and applied training method (off the job and on the job).

3. In this phase, we selected training programmes for analysis. The list of programmes was chosen based on the consultations with members from National Cluster Association operating in the Czech Republic. Selection criteria for programmes on the European level were the following: organisation/initiative is offering a training programme for more than 3 years; the training programme must be international. The final list included ten international programmes.

4. Finally, we analyzed content of each programme and assignment appropriate category of skills (hard/soft) to these programmes. Specifically, a content analysis was applied - a systematic, replicable technique for compressing many words of text into fewer content categories based on explicit rules of coding (Krippendorff, 1980; Weber, 1990).

Table 1 Developed categories for comparative analysis, own processing

\begin{tabular}{|l|l|}
\hline Category & Definition \\
\hline Hard skills focus & $\begin{array}{l}\text { Terms related to specific cluster knowledge } \\
\text { (tools/methods for cluster setting/development; } \\
\text { cluster policy), knowledge in management } \\
\text { area. }\end{array}$ \\
\hline Soft skills focus & $\begin{array}{l}\text { Terms related to intrapersonal skills (one's } \\
\text { ability to manage oneself) and interpersonal } \\
\text { skills (how one handles one's interactions with } \\
\text { others). }\end{array}$ \\
\hline
\end{tabular}

\section{COMPARATIVE ANALYSIS OF INTERNATIONAL TRAINING PROGRAMMES AND ACTIVITIES FOR CLUSTER MANAGERS}

The organisations offering training for cluster managers are spread worldwide. They provide education for novice, but also for skilled managers who want to stay oriented in actual trends. The common goal is to keep cluster management at high quality in order to develop relevant cluster organisation. The success of cluster organisation then leads to innovation and economic development in the whole region. In this chapter, we focus on analysis of international current programmes aimed at the development of cluster managers. Further characteristics of these programmes including area of developed skills is given within Tab. 2 (the information were collected via websites of organizations / initiatives TCI, Oxford Research Group Quercus, Cluster Navigators, Clusterland Upper Austria, Cluster Development, EFCE and Business School - see references). 
Table 2 International training programmes and activities for cluster managers, own processing

\begin{tabular}{|c|c|c|c|c|c|c|}
\hline \begin{tabular}{|c|} 
Name of the \\
programme/activity
\end{tabular} & \begin{tabular}{|c|} 
Organiza- \\
tion/Initiati \\
ve
\end{tabular} & Brief content and focus & Duration & Place & $\begin{array}{l}\text { Training } \\
\text { method }\end{array}$ & \begin{tabular}{|c|} 
Category of \\
developed \\
skills
\end{tabular} \\
\hline $\begin{array}{l}\text { Mentoring for } \\
\text { cluster managers }\end{array}$ & TCI & $\begin{array}{l}\text { Analysis and benchmark of other cluster initiatives; } \\
\text { international cooperation; project collaboration; } \\
\text { communication skills. }\end{array}$ & $\begin{array}{l}\text { Long- } \\
\text { term. }\end{array}$ & $\begin{array}{l}\text { Mainly } \\
\text { through } \\
\text { videoconferen } \\
\text { cing. }\end{array}$ & $\begin{array}{l}\text { On the job } \\
\text { training. }\end{array}$ & $\begin{array}{l}\text { Hard skills, } \\
\text { soft skills. }\end{array}$ \\
\hline $\begin{array}{l}\text { International } \\
\text { course for cluster } \\
\text { management }\end{array}$ & $\begin{array}{l}\text { Oxford } \\
\text { Research }\end{array}$ & $\begin{array}{l}\text { Theoretical and practical knowledge about clusters and } \\
\text { cluster development; life cycles of cluster; understanding } \\
\text { of different cluster policies and approaches; management } \\
\text { and facilitation of clusters; tools and methods for } \\
\text { development of clusters; evaluation and monitoring of } \\
\text { clusters. }\end{array}$ & $\begin{array}{l}\text { Short- } \\
\text { term. }\end{array}$ & Copenhagen. & $\begin{array}{l}\text { Off the job } \\
\text { training. }\end{array}$ & Hard skills. \\
\hline $\begin{array}{l}\text { Training - How to } \\
\text { make your cluster a } \\
\text { success }\end{array}$ & $\begin{array}{l}\text { Quercus } \\
\text { Group }\end{array}$ & $\begin{array}{l}\text { Ways to ensure the successful development of the cluster; } \\
\text { tools for organizing, managing and internationalization of } \\
\text { clusters; the possibilities of gaining new members to the } \\
\text { cluster. }\end{array}$ & $\begin{array}{l}\text { Short- } \\
\text { term. }\end{array}$ & Copenhagen. & $\begin{array}{l}\text { Off the job } \\
\text { training. }\end{array}$ & Hard skills. \\
\hline $\begin{array}{l}\text { Interactive training } \\
\text { courses }\end{array}$ & $\begin{array}{c}\text { Cluster } \\
\text { Navigators }\end{array}$ & $\begin{array}{l}\text { Courses are based on a concept called "Twelve steps" } \\
\text { leading to the development of the cluster - participants } \\
\text { gain the skills to identify clusters in the region, to } \\
\text { implement cooperative development strategy involving } \\
\text { private operators, public administrations, academic } \\
\text { municipalities and also to mobilize and recruit key } \\
\text { enterprises needed for the development of the cluster. }\end{array}$ & $\begin{array}{l}\text { Short- } \\
\text { term. }\end{array}$ & $\begin{array}{l}\text { Intensive } \\
\text { training } \\
\text { courses which } \\
\text { take place in } \\
\text { the countries } \\
\text { of candidates. }\end{array}$ & $\begin{array}{l}\text { Off the job } \\
\text { training. }\end{array}$ & Hard skills. \\
\hline $\begin{array}{l}\text { Clusterland Cluster } \\
\text { Academy }\end{array}$ & $\begin{array}{l}\text { Clusterland } \\
\text { Upper } \\
\text { Austria }\end{array}$ & $\begin{array}{l}\text { Marketing \& PR; cooperation projects as a source of } \\
\text { innovation; knowledge management; internationalization; } \\
\text { qualification / events; financing of cluster organizations; } \\
\text { evaluation and performance measurement tools of cluster } \\
\text { organizations; cluster Tour. }\end{array}$ & $\begin{array}{l}\text { Short- } \\
\text { term. }\end{array}$ & Linz. & $\begin{array}{l}\text { Off the job } \\
\text { training. }\end{array}$ & Hard skills. \\
\hline \begin{tabular}{|l|} 
Cluster Training \\
\end{tabular} & \begin{tabular}{|c|} 
Cluster \\
Developme \\
$\mathrm{nt}$
\end{tabular} & $\begin{array}{l}\text { Basic and advanced courses for the development of } \\
\text { clusters; cluster policy and competitiveness; training with } \\
\text { the help of practical examples. }\end{array}$ & $\begin{array}{l}\text { Medium- } \\
\text { term. }\end{array}$ & $\begin{array}{l}\text { Online and } \\
\text { offline } \\
\text { (depends on }\end{array}$ & $\begin{array}{l}\text { Off the job } \\
\text { training. }\end{array}$ & Hard skills. \\
\hline
\end{tabular}




\begin{tabular}{|c|c|c|c|c|c|c|}
\hline & & & & $\begin{array}{l}\text { the type of the } \\
\text { course). }\end{array}$ & & \\
\hline Train-the-Trainers & EFCE & $\begin{array}{l}\text { The programme consists of } 10 \text { courses focusing on the } \\
\text { development possibilities of the cluster including the } \\
\text { processing of the project on the basis of gained } \\
\text { theoretical information. }\end{array}$ & $\begin{array}{l}\text { Long- } \\
\text { term. }\end{array}$ & Barcelona. & $\begin{array}{l}\text { Off the job } \\
\text { training. }\end{array}$ & Hard skills. \\
\hline $\begin{array}{l}\text { Competitiveness } \\
\text { School for Leading } \\
\text { Regions, Clusters } \\
\text { and Cities }\end{array}$ & $\begin{array}{l}\text { EFCE and } \\
\text { IESE } \\
\text { Business } \\
\text { School }\end{array}$ & $\begin{array}{l}\text { Policy for competitiveness module - policy best practices } \\
\text { in competitiveness and economic development for senior } \\
\text { economic policymakers and development professionals; } \\
\text { topics: regional competitiveness, cluster competitiveness, } \\
\text { city competitiveness, competitiveness in action. } \\
\text { Management for competitiveness module - strategic } \\
\text { methodologies and frameworks to be used in } \\
\text { competitiveness development for managers at all levels; } \\
\text { topics: strategic tools for competitiveness, management } \\
\text { tools, summary of all topics including panel discussions. }\end{array}$ & $\begin{array}{l}\text { Short- } \\
\text { term. }\end{array}$ & Barcelona. & $\begin{array}{l}\text { Off the job } \\
\text { training. }\end{array}$ & Hard skills. \\
\hline $\begin{array}{l}\text { The Essence of } \\
\text { Cluster Excellence } \\
\text { Management }\end{array}$ & EFCE & $\begin{array}{l}\text { Cluster economics; cluster initiative screening; industry } \\
\text { analysis and segmentation; value chain analysis; } \\
\text { benchmarking and internationalization of SMEs. } \\
\text { + possibility to choice further optional course. }\end{array}$ & $\begin{array}{l}\text { Long- } \\
\text { term. }\end{array}$ & $\begin{array}{l}\text { 1st and 5th } \\
\text { week consists } \\
\text { of seminars } \\
\text { and } \\
\text { workshops } \\
\text { held in } \\
\text { Barcelona. }\end{array}$ & $\begin{array}{l}\text { Off the job } \\
\text { training. }\end{array}$ & Hard skills. \\
\hline $\begin{array}{l}\text { Gold Cluster } \\
\text { Excellence } \\
\text { Manager }\end{array}$ & EFCE & $\begin{array}{l}2 \text { parts: theoretical (content of the topics is same as in the } \\
\text { programme The Essence of Excellence Cluster } \\
\text { Management); practical (project realization which builds } \\
\text { on theoretical knowledge from courses). }\end{array}$ & $\begin{array}{l}\text { Long- } \\
\text { term. }\end{array}$ & $\begin{array}{l}5 \text { weeks of } \\
\text { theory, 1st } \\
\text { and 5th week } \\
\text { is held in } \\
\text { Barcelona. }\end{array}$ & $\begin{array}{l}\text { Off the job } \\
\text { training } \\
\text { and on the } \\
\text { job } \\
\text { training. }\end{array}$ & Hard skills. \\
\hline
\end{tabular}




\section{RESULTS AND DISCUSSION}

Regarding analyzed international programmes, the interesting findings appeared. The duration of programmes was divided into short-term ( $1-5$ days), medium-term $(2-4$ weeks $)$ and long-term (more than 1 month) course. The programmes are mostly conceived as short-term, the place of event is dependent on the organisation. The longest current programmes are Mentoring for cluster managers and Gold Cluster Excellence Manager). These two courses are characteristic by their complexity and therefore take over 6 months to finish. The organisation providing the most training possibilities is called European Foundation for Cluster Excellence (EFCE). It is training academy based in Barcelona and it aims to promote the use of clusters and value chains as an effective tool for the economic development of regions. In most of the programmes, off the job training method is applied. They are designed as seminars/workshops in separate place from the job environment. One of exception is programme Mentoring for cluster managers, which is characteristic for one-to-one interaction and belongs to on the job training method (within the work environment). The programme Gold Cluster Excellence Manager combines both training methods. Nevertheless, it cannot be said which of these two possible training methods is more efficient. At the moment, there is either no research or data which would support any of these methods within cluster conditions. Generally, the effective training method should: motivate the trainee to improve his or her performance, clearly demonstrate desired skills, provide an opportunity for active participation by the trainee, provide an opportunity to practice, be structured from simple to complex tasks, be adaptable to specific problems, encourage positive transfer from training to the job and so on (Woods, 1995). However, further research needs to be done between cluster managers and these mentioned factors could be subject of this investigation.

Main fact of the analyzed programmes is the lack of developing soft skills. Most of the programmes focus on the hard skills of cluster managers. Each of the international programmes involve education in the cluster area. The participants of these courses gain specific knowledge and abilities required for success in the cluster manager position - such as knowledge about identifying cluster, tools and methods for development of clusters and so on. Current focus on developing hard skills within these programmes may be due to the fact that soft-skills training is significantly less likely to transfer to the job than hard-skills training (Laker \& Powell, 2011) and are also hardly measurable. However, given the importance of soft skills (intrapersonal and interpersonal skills) in the context of effective management, their development is crucial. Also according to the cluster managers (Pro INNO Europe initiative, 2009) soft skills (namely comunication skills and leadership) are seen as the most important for successful and effective management of cluster organisation. This is also supported in study by Gebhardt and Pohlmann (2013), where interviewed cluster managers mention social networking as an essential. Porvazník (2014) adds that managers must reach a certain level of holistic eligibility which is reflected in having not only hard and soft skills, but also appropriate properties and attitudes. Thus, the trainings should develop managers complexly. Last but not least, it is important that organisations update their trainings according to the actual needs in the modern economic market (Belizón et al., 2016).

\section{CONCLUSIONS}

The purpose of the article was to analyze and evaluate training programmes for cluster managers across Europe with respect to their focus on the development of hard and soft skills. To achieve our objective, desktop research was conducted. To sum up, ten international 
programmes/activities were examined in the paper. Based on the gathered data, we state that most of the analyzed programmes focus on the hard skills of cluster managers. Nevertheless, the development of soft skills is needed to achieve a competitive advantage (Crosbie, 2005; Hunt a Baruch, 2003). Organisations/initiatives offering training programmes for cluster managers should consider these findings in order to make them more attractive and effective. Overall, as Jarjabka and Weiner (2012) state, the development of cluster managers will be a decisive competitive advantage in the future. It also supports innovation in cluster organisation, which requires a certain level of creativity, knowledge and relationship skills of all involved subjects (Jarjabka and Weiner, 2012). Bearing in mind that conditions for success today's turbulent markets have changed considerably, it is needed to pursue development of cluster managers in order to ensure sustainability of appropriate cluster organisation.

Considering the limitation of the article, it should be noted that the paper works only with secondary data. Another limitation is about choosing training programmes for cluster managers. Analyzed programmes were chosen according to the consultations with members of National Cluster Association, who have rich experience (over 10 years) in the field of cluster development. The composition of programmes would be different if the consultations were made with other subjects interested in cluster management development. The article also does not contain all available international training programmes for cluster managers. The focus was mainly given to the programmes which are under the organisations providing training for cluster managers over 3 years.

As regards direction for further research, the focus could now be given on evaluation of effectiveness training programmes, respectively methods done in Europe. This could bring interesting findings regarding pros and cons of those programmes from the cluster managerls point of view, followed by suggestions for improvement to make them more effective. This could be followed by analysing training programmes for cluster managers in some period of time. Interesting facts could emerge in the context of evolving these programmes, whether their topics are changing over time or not. The further research could also be focused on proposal training programme for cluster managers developing soft skills (such as communication skills, leadership skills, team working, organising and planning skills, etc.). The current programmes are mainly aimed on developing hard skills; adequate offers adressing soft skills are missing. Further research could also be focused on proposal selfdevelopment programmes for cluster management. Current courses are overwhelmingly conducted via training, lecturing, seminars and workshops. However, given the limited financial resources in the most of cluster organisations (Sölvell, Lindqvist and Ketels, 2003), the self-development method seems a good way to go. The advantage of self-development is particularly in flexibility - managers can plan appropriate development activities according to their temporal needs. Another reason to support this method is the fact that in cluster organizations are missing specific departments ensuring staff development.

\section{ACKNOWLEDGMENTS}

The authors are thankful to the Internal Grant Agency of UTB IGA/FaME/2016/010 "Evaluation and management of cohesion policy interventions in relation to territorial development, with emphasis on the thematic area of smart city," which provided financial support for this research. 


\section{REFERENCES}

Alipour, M., Salehi, M., \& Shahnavaz, A. (2009). A study of on the job training effectiveness: Empirical evidence of Iran. International Journal of Business and Management, 4(11), 63.

Alvesson, M., \& Sveningsson, S. (2003). Managers doing leadership: The extraordinarization of the mundane. Human relations, 56(12), 1435-1459.

Armstrong, M., 2007. Řizení lidských zdrojů - Nejnovějši trendy a postupy. 10. vyd. Praha: Grada Publishing, a.s. 800 s. ISBN 80247-1407-3.

Balcar, J. (2016). Is it better to invest in hard or soft skills? The Economic and Labour Relations Review, 27(4), 453-470.

Balcar J, Homolová E, Karásek Z, et al. (2011) Transferable Competences across Economic Sectors: Role and Importance for Employment at European Level. Luxembourg: Publications Office of the European Union (version without appendices).

Barry, D. (1991). Managing the Bossless Team: Lessons in Distributed Leadership. Organizational dynamics, 20(1), p. 31-47. doi: 10.1016/00902616(91)90081-J.

Belizón, M. J., Morley, M. J., \& Gunnigle, P. (2016). Modes of integration of human resource management practices in multinationals. Personnel Review, 45(3), 539-556.

Brodský, Z., 2009. Řizení lidských zdrojü pro managery: pro kombinované studium studijního programu Ekonomika a management. Pardubice: Univerzita Pardubice, Ekonomickosprávní fakulta, $113 \mathrm{~s}$. ISBN 978-80-7395-155-9.

Břusková, P., Hudečková, E., Poledník, J., Šarlej, M., \& Ochodek, T. (2013). Podstata a fungováni klastrových iniciativ. Retrieved from: http://partnerstvienergetiky.msek.cz/wp-content/uploads/2013/01/06-Podstata-a-fungovani-klastrovychiniciativ.pdf.

Cloe: Clusters Linked over Europe. (2006). Cluster Management Guide - Guidelines for the Development nad Management of Cluster Initiatives. Linz: TMG. Dostupné z: http://www.interreg4c.eu/uploads/media/pdf/2_Cluster_Management_Guide_CLOE.pdf

Cluster Development. (2016). Cluster Training. In: Cluster Development [online]. Dostupné z: http://www.cluster-development.com/cluster/en/Cluster_training.

Cluster Navigators. (2016). Cluster Development - Training Workshops. In: Cluster Navigators [online]. Dostupné z: http://www.clusternavigators.com/workshops.cfm.

Cooke, P. (2001). Regional innovation systems, clusters, and the knowledge economy. Industrial and corporate change, 10(4), 945-974.

Cosh, A., Duncan, J. and Hughes, A. (1998) Investment in Training and Small Firm Growth and Survival. Department for Education and Employment, Research Report RR 36, Sheffield.

Crosbie, R. (2005). Learning the soft skills of leadership. Industrial and commercial training, 37(1), 45-51.

Darling, J. R., \& Heller, V. L. (2009). Organization development in an era of socioeconomic change: A focus on the key to successful management leadership. Organization development journal, 27(2), 9.

Doronina, I. I., Kulikova, N. N., Razzhivin, O. A., Kostyukhin, Y. Y., Silnov, D. S., \& Sadovnikova, N. A. (2016). Human resource management features of an innovative cluster. International Review of Management and Marketing, 6(6S).

Drucker, P. F. (2012). To nejdi̊ležitějšš z Druckera v jednom svazku. 1. vyd. Praha: Management press, 300 s. ISBN 978-807261-242-0. 
Du Plessis, A., Frederick, H., \& Maritz, A. (2013). Education and training deficits in industrial clusters: Empirical evidence that managers can use to rectify the skills gap in Auckland precinct. Actual Problems of Economics, 2(3), 12-20.

Elmuti, D., Minnis, W., \& Abebe, M. (2005). Does education have a role in developing leadership skills?. Management Decision, 43(7/8), 1018-1031.

European Foundation for Cluster Excellence. (2016a). Train-the-Trainers. In: Towards Excellence in Cluster Management [online]. Dostupné z: http://www.clusterexcellence.org/trainthetrainers/.

European Foundation for Cluster Excellence. (2016b). Competitiveness Summer School For Leading Regions, Clusters and Cities Barcelona, Autumn 2016. In: Towards Excellence in Cluster Management [online]. Dostupné http://www.clusterexcellence.org/summer-school/.

European Foundation for Cluster Excellence. (2016c). The Essence of Cluster Excellence Management. In: Towards Excellence in Cluster Management [online]. Dostupné z: http://www.clusterexcellence.org/essence/.

European Foundation for Cluster Excellence. (2016d). Gold Cluster Excellence Manager. In: Towards Excellence in Cluster Management [online]. Dostupné z: http://www.clusterexcellence.org/gold/.

Folwarczná, I., 2010. Rozvoj a vzdělávání manažerů. 1. vyd. Praha: Grada. 240 s. ISBN $978-$ 80-247-3067-7.

Fraser, S., Storey, D., Frankish, J. and Roberts, R. (2002). The Relationship between Training and Small Business Performance: An Analysis of the Barclays Bank Small Firms Training Loan Scheme. Environment and Planning C, 20(2): 211-34.

Freeman, W. J. (2007). Moral maturity and the knowledge management firm. Nova Southeastern University: ProQuest. 142 s. ISBN 978-0-549-20287-5.

Gebhardt, C., \& Pohlmann, M. C. (2013). Managing the organisation 2.0: Entrepreneurial spirit and general management competences as early indicators for cluster success and sustainable regional development: Findings from the German Entrepreneurial Regions Programme. The Journal of High Technology Management Research, 24(2), 153-160.

Günther, J., \& Meissner, D. (2017). Clusters as Innovative Melting Pots?-the Meaning of Cluster Management for Knowledge Diffusion in Clusters. Journal of the Knowledge Economy, 1-14.

Henville, N. (2012). Hard vs soft skills training. Training Journal, 21(2), 41-44.

Hunt, J. W., \& Baruch, Y., 2003. Developing Top Managers: the Impact of Interpersonal Skills Training. Journal of Management Development, 22(8), p. 729-752. doi: http://dx.doi.org/10.1108/02621710310487882.

Ingstrup, M. B., \& Damgaard, T. (2013). Cluster Facilitation from a Cluster Life Cycle Perspective. European Planning Studies, 21(4), p. 556-574. doi: http://dx.doi.org/10.1080/09654313.2012.722953.

Jarjabka, Á., \& Weiner, J. (2012). The Importance and Aspects of Training in EU Cluster Development. Közgazdász Fórum, 15(109), p. 29-47.

Kars-Unluoglu, S. (2016). How do we educate future innovation managers? Insights on innovation education in MBA syllabi. Innovation, 18(1), 74-98.

Kergel, H., zu Köcker, G. M., \& Nerger, M. (2014). New Approaches to Improve the Performance of Cluster Management Organisations in Europe. Berlin: European Secretariat for Cluster Analysis (ESCA). Dostupné z: http://www.clusteranalysis.org/downloads/Newapproachestoimprove.pdf.

Kitching, J. \& Blackburn, R. (2002). The Nature of Training and Motivation to Train in Small Firms. Research Report RR 330, Sheffield: Department for Education and Skills. 
Knorringa, P., \& Meyer-Stamer, J. (1998). New dimensions in local enterprise cooperation and development: from clusters to industrial districts. New Approaches to Science and Technology Cooperation and Capacity Building. New York, Geneva: United Nations (atas XI).

Krippendorff, K. (1980), Content Analysis: An Introduction to Its Methodology. Newbury Park, CA: Sage.

Laker, D. R., \& Powell, J. L. (2011). The differences between hard and soft skills and their relative impact on training transfer. Human Resource Development Quarterly, 22(1), 111-122.

Martin, R., \& Sunley, P. (2003). Deconstructing clusters: chaotic concept or policy panacea?. Journal of economic geography, 3(1), 5-35.

Mazilu, M., \& Sava, C. (2011). New ways of Innovation in Tourism Economy: implementing Clusters, in Recent Researches in Economics, Proceedings of the 2-nd 669 International Conference on Business Administration (ICBA'2011), Montreux, Switzerland. Retrieved from: http://www.wseas.us/elibrary/conferences/2011/Montreux/ICICIC/ICICIC-11.pdf.

McGurk, P. (2013). Management and leadership development in public service organizations. Human resource management in the public sector.

McKenna, J. F., \& Yeider, R. A. (1991). Management Development for an Organisation in Transition. Journal of Management Development, 10(1), 54-63.

Menu, S. (2012). The role of cluster policy on leadership: evidence from two Pôles de compétitivité. Environment and Planning C: Government and Policy, 30(5), 816-834.

Millar, C., \& Gitsham, M. (2013). The role of management development in achieving a culture change towards sustainability in the organisation. Journal of Management Development, 32(3).

Mühleisen, S. Oberhuber, N. (2008). Komunikační a jiné měkké dovednosti. Soft skills v praxi. 1. vyd. Praha: Grada Publishing.

Nguyen, N., \& Hansen, J. Ø. (2016). Becoming a leader-manager: a matter of training and education. Development and Learning in Organizations: An International Journal, 30(6), 10-12.

Northouse, P. G. (2013). Leadership: Theory and Practice. 6 vyd. Los Angeles: Sage, 481 s. ISBN 978-1-4522-0340-9.

Pavelková, D., Friedel, L., Jirčíková, E., Knápková, A., Skokan, K., \& Škodáková, P. (2009). Klastry a jejich vliv na výkonnost firem. 1. vyd. Praha: Grada Publishing, a.s. 268 s. ISBN 978-80-247-2689-2.

Porter, M. (1990). The competitive advantage of nations. New York: The Free Press.

Porvazník, J. (2014). Celostní management. Třetí přepracované a doplněné vydání. Bratislava: IRIS. ISBN 978-80-8153-030-2.

Pro Inno Europe Initiative. (2009). CMQ - Cluster Manager Qualification: Results of a Comprehensive Survey on Tasks, Skills \& Training Needs of European Cluster Managers. INNO-Net project CEE-Cluster Network. Dostupné z: http://www.clusterplattform.at/fileadmin/user_upload/clusterbibliothek/624_CMQsummary-report_CEE-CN_090428.pdf.

Quercus Group. (2016). Training - How to make your cluster a success [online]. In: Quercus Group. Dostupné z: http://www.quercus-group.com/\#!Signup-for-training-how-tomake-your-cluster-a-success-2-4-March-2016/c7a5/566a050f0cf2391068761d63.

Robinson, S., \& Stubberud, H. A. (2014). Teaching creativity, team work and other soft skills for entrepreneurship. Journal of Entrepreneurship Education, 17(2), 186. 
Salas, E., Wildman, J. L., \& Piccolo, R. F. (2009). Using simulation-based training to enhance management education. Academy of Management Learning \& Education, 8(4), 559-573.

Schretlen, J.H., Dervojeda, K., Jansen, W., \& Schaffmeister,, B.

Uncovering excellence in cluster management. Price

(2011).

Accountants

Dostupné

waterhouse

Coopers http://www.pwc.com/en_GX/gx/psrc/pdf/cluster_management.pdf.

Sölvell, Ö., Lindqvist, G., \& Ketels, C. (2003), The Cluster Initiative Greenbook. Stockholm: Ivory Tower Publishers. ISBN 91-974783-1-8. Dostupné z: https://www.hhs.se/contentassets/f51b706e1d644e9fa6c4d232abd09e63/greenbooksep0 3.pdf.

Statt, D. A. (1998). The concise dictionary of psychology. Taylor \& Francis US. ISBN 0-20345052-3.

Steiner, M., \& Hartmann, C. (2006). Organizational learning in clusters: A case study on material and immaterial dimensions of cooperation. Regional Studies, 40(5), 493-506. doi: http://dx.doi.org/10.1080/00343400600757494.

Storey, D.J. (2002). Education, Training and Development Policies and Practices in Medium and Small Sized Enterprises in the UK: Do They Really Influence Firm Performance?. Omega, 30:249-64.

Storey, D. J. (2004). Exploring the link, among small firms, between management training and firm performance: a comparison between the UK and other OECD countries. The International Journal of Human Resource Management, 15(1), 112-130.

Swann, P., \& Prevezer, M. (1996). A comparison of the dynamics of industrial clustering in computing and biotechnology. Research Policy, 25(7), 1139-1157. doi: http://dx.doi.org/10.1016/S0048-7333(96)00897-9.

Sydow, J., Lerch, F., Huxham, C., \& Hibbert, P. (2011). A silent cry for leadership: Organizing for leading (in) clusters. The Leadership Quarterly, 22(2), p. 328-343. doi: 10.1016/j.leaqua.2011.02.008.

Tannenbaum, S. I., \& Yukl, G. (1992). Training and development in work organizations. Annual review of psychology, 43(1), 399-441.

Ulčín, P. (2014). Ryba smrdi od hlavy. Jak firma přijde o milion. In: Moderní řizení. Měsíčník vydavatelství Economia. 4(10), p. 32-34. ISSN 0026-8720.

Urban, J., 2004. Výkladový slovník rízení lidských zdrojů: s anglickými ekvivalenty. Praha: ASPI. ISBN 807357019X.

Veber, J. (2014). Management: základy, moderní manažerské přistupy, výkonnost a prosperita. 2.vyd. Praha: Management Press, 736 s. ISBN 978-80-726-1274-1.

Weber, R. P. (1990), Basic Content Analysis. Newbury Park, CA: Sage.

Woods, R. (1995). Human Resources Management. AHMA, Michigan.

Zagorsek, H., Svetina, A. C., \& Jaklic, M. (2008). Leadership in clusters: Attributes of effective cluster leader in Slovenia. Transformations in Business and Economics, 7(2), p. $98-113$. 